\title{
Reconciling the classes
}

Many contemporaries were convinced that by the 1960s class barriers had been at least attenuated compared with the 1930s. The children of manual workers were believed to be better able to enter the middle class; and it was thought that many of those remaining on the factory floor were adopting bourgeois ways. Labour members appeared more divided over this issue than they actually were. While the left considered 'affluence' made only a modest impact on the social structure and revisionists thought its influence profound, few denied Britain remained a society tainted by class. In 1956, Labour's conference approved Towards Equality, a document broadly in tune with revisionist thinking and which confirmed the existence of 'a strong, persistent trend towards economic and social inequality'. ${ }^{1}$ Even Anthony Crosland, who in the same year predicted that 'primary poverty' (i.e. insufficient incomes) would disappear by the mid-1960s, still considered inequality a serious problem that only government action could finally eradicate. ${ }^{2} \mathrm{~A}$ key element in Labour's solution to the persistence of class differences was the fostering of a common culture based on co-operation rather than conflict. This chapter looks at secondary education and industrial democracy to assess how Harold Wilson's governments tried to promote this culture - and why they failed.

If Labour derived most of its electoral support from manual workers and was dependent on trade union money, it was not a class party in the Marxist sense. The desirability of promoting an identity other than one based on class had inspired much Labour thinking since at least Ramsay MacDonald's day. Accordingly, Reginald Sorenson, MP for Leyton until elevated to the Lords in 1965, believed that, whatever a person's class, all were 'members of a common humanity' and needed to nourish what the poet William Blake referred to as 'Mercy, Pity, Peace and Love' or succumb to 'lethal enmities'. ${ }^{3}$ Similarly, Norman Willis, a young activist in Surrey - and incidentally a future General Secretary of the Trades Union Congress (TUC) - conceived of socialism as a society in which 'people really feel a sense of identity between themselves and 
their neighbours'. ${ }^{4}$ More pertinently, Wilson's appeal to the 'useful people' (see Chapter 3) proceeded from the assumption that the working and middle classes shared a common economic interest, against which their other differences paled.

Towards Equality confirmed Labour's commitment to reduce inequality through 'deliberate and continuous State intervention'. ${ }^{5}$ For many on the left, this meant ensuring the economy was dominated by the state. So far as the leadership was concerned, however, nationalisation was less important than maintaining full employment, increasing taxes on unearned wealth, creating a more generous welfare system and, most crucially, accelerating economic growth. While this did not imply totally abolishing income inequality, it nonetheless required establishing a 'decent' minimum income and ensuring differentials reflected the nature of the work undertaken. ${ }^{6}$ If confident their policies would promote a greater equality of outcome, revisionists still believed the party needed to take further steps to increase equality of opportunity, for, despite rising incomes, only the fortunate few were exploiting their full potential. Hugh Gaitskell, for one, considered a society where class origin determined opportunity and in which there were 'feelings or attitudes of superiority or inferiority between groups' could not be considered egalitarian. ${ }^{7}$ So far as revisionists - and others in the party for that matter - were concerned, this meant focusing on culture as much as on the economy, in particular ending segregated secondary education.

If most Labour members agreed that education needed reform, a similar consensus was lacking over how to establish workplace harmony. ${ }^{8}$ Despite rising incomes, Britain's industrial relations record suggested the point of production remained the main venue for class conflict. Indeed, soon after Wilson entered Downing Street, class feeling - as measured in terms of number of strikes - increased. Industrial democracy appeared a possible solution, as it was hoped it would improve workers' status, help them develop their own potential and promote co-operation. However, while it appeared to some to be a panacea, it raised awkward and fundamental questions that Labour was unable to resolve. While all in the party aspired to create a more peaceful industrial scene, members were seriously at odds regarding on whose basis the employers' or the unions' - co-operation should proceed.

\section{Stopping snobbery}

As the junior education minister Alice Bacon declared in 1969, Labour believed education was 'not only the means of individual development, but an instrument for the creation of a better society'. ${ }^{9}$ The 1964 manifesto promised a 'revolution in our educational system' that would: 
reduce class sizes; raise the school-leaving age from fifteen to sixteen years; improve technical training; and increase the number of places in higher education. The main emphasis was, however, on reforming secondary education, in particular abolishing segregated schooling. Labour's overall aim was to equalise opportunities, to improve individual attainment and to increase economic output, as it was asserted that a fairer society would be more productive. ${ }^{10}$

The 1945-51 Labour governments had applied the 1944 Education Act (passed by the wartime coalition) because it enshrined the principle of universal free secondary education. ${ }^{11}$ Hitherto, those who had won entry to grammar school by taking a competitive examination at the age of ten were expected to pay a variety of costs: this impeded the progress of working-class children. So long as all children of talent could win free places in grammar schools, most members were little troubled by the fact that they continued to be separated by examination, with at most 20 per cent going to grammar schools and the rest entering secondary modern schools. Even so, Labour was formally committed to experimenting with 'common' or comprehensive schools that transcended the grammar-secondary-modern divide. If ministers were uninterested in innovation, Labour-controlled local authorities in places such as London and Coventry built comprehensives. Subsequent investigations also revealed the system established after 1945 was not as fair as some thought, because middle-class offspring dominated grammar schools owing to advantages imbued by family background rather than innate intelligence. ${ }^{12}$

After 1951, support grew for a change to party policy and by 1955 Labour was committed to actively promoting comprehensive education. ${ }^{13}$ The extent to which this shift was based, as Labour's then deputy leader James Griffiths claimed, on an empirical assessment of the educational system's defects is moot. ${ }^{14}$ Michael Stewart and Margaret Cole leading party thinkers on this subject - certainly believed most members did not object to ten-year-olds being examined but strongly opposed their segregation. ${ }^{15}$ Towards Equality had also stressed the social harm done to children educated in separate institutions, and concluded that it was incompatible with a classless society. ${ }^{16}$ It was not until 1970 that conference delegates expressed interest in how children were taught in the new schools. Even then, their concern was mostly limited to the fact that they often streamed pupils along academic lines, meaning children were still taught in groups differentiated by background. ${ }^{17}$

Most of the arguments members used to convince each other of the merits of comprehensive schooling therefore relied on social criteria: a 1953 headline in London News even dubbed them 'Schools to Stop Snobbery'. ${ }^{18}$ As one Abingdon alderman put it, in a comprehensive school, children of '[a]ll levels of intelligence play games together, join 
the same school clubs and eat together' and were subject to the 'same standards of behaviour, manners and social responses'. ${ }^{19}$ Members in North Kensington were urged to support comprehensives because 'if everybody, whatever job they were to perform later in life' were educated together, they would enjoy a 'common social and cultural background' and create 'a happier, more united and less class conscious nation'. ${ }^{20} \mathrm{~A}$ comprehensive, members of a 1957 National Executive Committee (NEC) Study Group on Education believed, could 'benefit both bright and less bright children' by acting as a 'useful focus' for the growth of 'community spirit'. ${ }^{21}$

While some local Labour authorities promoted comprehensives, most remained loyal to grammars, which still retained popular support. In the late $1950 \mathrm{~s}$, a Transport House survey revealed that only a small minority of parents questioned the educational status quo; however, while no more than 10 per cent believed selection undesirable, once the case for comprehensives was put, over half wanted reform. ${ }^{22}$ The party's argument in favour of comprehensives was consequently tailored to win over doubters by stressing the unfairness of selection while guaranteeing that the standards established by grammar schools would be maintained. Writing in 1964, one Bristol activist acknowledged that grammar schools had a fine tradition but argued that comprehensive schools would provide 'an education in tune with the democratic 1960's which allows every child to fully develop his talents'. ${ }^{23}$ The impression that class division was already weakening possibly helped the party make its case, for it was argued at its 1967 annual conference that segregation maintained 'rigid and unjust divisions' at a time when 'social barriers should be crumbling'. ${ }^{24}$

Even so, members remained at odds over the issue, with some activists complaining that it was not just Conservatives who opposed comprehensives: their own local representatives could be equally 'backward'. ${ }^{25}$ The nature of the division was highlighted during 1966 in the columns of Warwick and Leamington Spa's constituency magazine. This contained an article praising comprehensives for encouraging the spirit of co-operation and mutual respect and so showing society a way of escaping the 'jungle of capitalism'. That view was criticised by a lifelong member who believed comprehensives denied the hereditary basis to education, for if middle-class children won grammar places it was because they were 'innately more clever' than the rest. While 'it would be very nice if the mental inferiority of working-class children could all be explained away', this member believed it could not. ${ }^{26}$

The Wilson governments' move towards a national comprehensive system was slower than enthusiasts demanded. ${ }^{27}$ Crosland's personal dedication to reform while he was at the Department for Education, however, should not be doubted: as he announced to his wife, even if it 
was 'the last thing I do, I'm going to destroy every fucking grammar school in England. And Wales. And Northern Ireland'. ${ }^{28}$ Crosland was mistaken about Northern Ireland, as his remit did not run there; and nor did it extend to Scotland. Moreover, while mostly funded by central government, education in England and Wales was the responsibility of 163 local education authorities. Without altering that relationship, Crosland could not impose his will directly. Thus, in July 1965 he only requested authorities submit plans for the reorganisation of education along comprehensive lines. Much was done to encourage reluctant authorities to toe the line. A year later he announced that only those authorities committed to comprehensive education would be granted funds to build new schools. This, at least, accorded with party policy as articulated by the earlier NEC Study Group on Education, which determined that comprehensives should develop according to 'local wishes and circumstances'. On that basis the Group calculated it would take at least fifteen years for the comprehensive system to become universal. ${ }^{29}$

Only a few authorities refused to adhere to Crosland's request, but he nonetheless sought compulsory powers. ${ }^{30}$ This was partly for political reasons. Such had been the transformation in attitudes to comprehensive schools that Labour strategists thought there were electoral advantages in forcing authorities to abide by government policy. They believed this would appeal particularly to middle-class parents living under rebel Conservative authorities, as they could ill-afford to send children who had flunked the grammar entrance examination to feepaying schools (on which, see below). ${ }^{31}$ Thus, when Wilson announced the date of the 1970 general election, legislation was in process to force authorities to adhere to the comprehensive principle. Even without that power, government had accelerated the move from selection, so that if 10 per cent of children were educated in comprehensives in 1964 by 1970 nearer one-third were. This proportion was guaranteed to rise, as most authorities had established a comprehensive system or had imminent plans to do so.

\section{Playgrounds for plutocrats}

The private sector comprised two different kinds of educational establishment: those termed 'public', whose intake was determined by the ability to pay; and what were described as 'grant maintained', which, in return for setting aside one-quarter of places to non-fee-payers, received a government subsidy. By June 1970, Labour had done nothing of substance to reduce their influence, despite Crosland considering it was the 'greatest single cause of stratification and class-consciousness in Britain'. ${ }^{32}$ 
Although private schools had long been thought inimical to socialism, Clement Attlee's ministers left them alone, with a few openly expressing their admiration for the education they provided. Even most reformers called only for a minority of public school places to be made available to non-fee-payers. ${ }^{33}$ As with comprehensives, after 1951 the leadership showed a greater determination to challenge the status quo, with revisionists taking a lead. In 1953 Gaitskell went so far as to urge the next Labour government to ensure that a majority of public school places were immediately made free and to abolish all fee-paying soon thereafter. ${ }^{34}$ Revisionists did not want to destroy private schools but sought to integrate them within the state sector. This meant they favoured change through agreement - which Crosland thought possible, if only because many private teachers felt guilty about perpetuating privilege. ${ }^{35}$ In contrast, while agreeing with their leaders' ends, most who spoke on the subject at Labour conferences demanded instant abolition.

Despite the consensus over aims, and the fact that the NEC Study Group on Education confirmed that private education was 'repugnant' to party principles, Labour members could not agree how to approach reform in time for the 1959 general election. ${ }^{36}$ With only a small minority favouring immediate abolition, the Group was initially inclined to stop grant maintained schools receiving state funds and to ensure that up to 75 per cent of public school places were opened to non-fee-payers. However, the former two proposals were thought politically dangerous and the latter raised an intractable issue, as it was unclear how non-feepayers should be selected. Gaitskell supported the use of intelligence tests for selection, although others contended this would not prevent public schools remaining socially exclusive. Whatever the criteria, selection was incompatible with Labour's support for comprehensives and it was to avoid this contradiction that friendly experts advised the Group either to recommend immediate radical change or to leave private education alone. Crosland agreed, as he thought limited change would merely endow private education with greater legitimacy. ${ }^{37}$ In any case, survey evidence indicated that voters broadly supported private schooling: 80 per cent - including a majority of the working class - claimed they would pay for their child's education if they could. ${ }^{38}$ Thus, having toyed with reform, the Group recommended that no action be taken, and it asserted Labour should instead concentrate on increasing investment in state schools and transforming them into comprehensives. The professed aim was to raise the standard of state education so that it would equal that provided by the private sector. ${ }^{39}$ Few thought this credible: Stewart and Cole calculated the former would need at least four decades to catch up with the latter. ${ }^{40}$

As part of the attempt to foster reconciliation within the party, Signposts for the Sixties embraced a radical approach to private education: it 
committed Labour to establishing an educational trust that would determine how to integrate private schools into the state system. ${ }^{41}$ As Bacon characterised it, Labour entered the 1964 campaign aiming to turn public schools from 'playgrounds for plutocrats into training grounds for democrats'. ${ }^{42}$ Labour's initially small majority encouraged Wilson and Michael Stewart, his first Education Secretary, to tread with caution. ${ }^{43}$ When Crosland replaced Stewart, however, he won Cabinet approval in November 1965 to establish a commission to make good the promise made in Signposts. This body was instructed to see how private schools could best be used 'to meet the needs of the nation' while eliminating their 'divisive influence'. If some feared ministers were wary of fundamental change, Crosland remained committed to making at least 75 per cent of public school places open to non-fee-payers. ${ }^{44}$ Even that would have disappointed contributors to conference debates: in 1967 the only speaker from the floor to advocate something other than immediate abolition was the MP Robert Maxwell, who was severely heckled for his trouble. ${ }^{45}$

After being turned down by his first five choices, Crosland secured the services of Sir John Newsom to chair the commission. Newsom proved ineffective and after much prevarication delivered but the first volume of his report in the summer of 1968. This agreed that private schools were divisive and that society would benefit if their pupils came from more diverse backgrounds. However, while proposing that public schools be deprived of their lucrative charitable status, the report did not propose bringing them within the state system. Moreover, much of the report focused on altering the intake of pupil boarders, with the suggestion that up to half of boarding places should go to non-fee-payers. ${ }^{46}$ This eccentric emphasis failed to impress. Edward Short, Crosland's successor, was disappointed, while Tony Benn described the report as 'ghastly': consequently the Cabinet agreed it should be published without comment, believing it best to await the final volume before drafting legislation. ${ }^{47}$

Even had Newsom made a better fist of his commission, 1968 was an inauspicious time for the government to take action: he called for spending on a few thousand children, while ministers had just delayed raising the school-leaving age for state pupils, in order to accommodate postdevaluation spending cuts. Endorsing the report would have further alienated already disenchanted activists, while taking a more radical line could have only reduced support among the middle class and made little impact on working-class voters, at a moment when Labour was losing elections at a record rate. Therefore, with NEC blessing, the 1968 conference rejected Newsom, with one delegate describing his proposal for more government support but not control as 'a travesty of Socialist principles'. ${ }^{48}$ 
The more radical David Donnison took responsibility for the second part of the commission's work and recommended the integration of grant maintained schools into a comprehensive state system. Unfortunately, his report was published in the run-up to the 1970 election and, as one member of the commission admitted, it threatened to antagonise middle-class parents, whose children were the main beneficiaries of free places. ${ }^{49}$ Once again, this was not the best of times to discuss a matter that could only lose Labour support; despite this, ministers were prepared to stop funding grant maintained schools by $1974 .^{50}$

It is not true, therefore, that Labour in power did nothing about private education: fee paying in grant maintained schools was abolished in Scotland, while a loophole was closed that allowed parents who borrowed money to pay fees to avoid tax. These were, however, modest measures, given the kind of impediment to an egalitarian society private education was believed to be. Perhaps Crosland had spoken more truly than he realised when laconically confiding to Cabinet in 1965 that private education posed a 'strictly insoluble problem' ${ }^{51}$

\section{Ministers and militancy}

If for none other than pressing economic reasons, Wilson's ministers wanted to promote a greater understanding between the classes at the workplace. While contemporaries influenced by Marxism believed that impossible, even leading left-wing Labour MPs, such as Ian Mikardo, thought conflict need not be endemic to industrial relations. In the early 1950s Mikardo had echoed arguments normally associated with revisionism when he suggested that the emergence of salaried, professional managers lacking the 'same urge to take unfair advantage of workers' as their inter-war predecessors meant both sides of industry could co-operate to mutual advantage. ${ }^{52}$ As the more mainstream veteran Scottish MP Arthur Woodburn stated in 1962, antagonism between worker and employer was '[o]ne of the greatest tragedies' of the contemporary scene and an entirely avoidable one at that. If irrational mistrust were overcome, he predicted, productivity would increase, 'scientific advance would leap ahead and poverty and a thousand ills would disappear'. ${ }^{53}$ That workers' rising living standards could be sustained only if they were based on improving productivity was a point reiterated with monotonous regularity by Wilson and his colleagues. ${ }^{54}$

From such a perspective, only politically malign or unaccountably obtuse groups would promote unrest. Thus, Wilson erroneously believed a dispute at the components firm Harvey Spicer, which broke out during the 1964 election campaign, was provoked by Conservative sympathisers to discredit Labour. ${ }^{55}$ Once in office, however, Wilson - as 
well as his Minister of Labour Ray Gunter and later Barbara Castle at the Department for Employment and Productivity (DEP) - was inclined to think disharmony the work of enemies to Labour's left, in particular the Communist Party (CP). The Cold War gave some credibility to these suspicions, as did the prominence of individual Communists in a number of unions. Wilson had, moreover, been warned by the security services that the CP saw strikes as one way of destroying his incomes policy (which it saw as exploiting workers), on the success of which so much hinged. ${ }^{56}$

Most on the left believed the leadership was biased against the unions. The government's response to industrial disputes was, however, often more conciliatory than confrontational, something illustrated by the 1967 rail strike. This was provoked by an inter-union dispute, between ASLEF, the rail drivers' union, and the National Union of Railwaymen, whose members were encroaching on traditional ASLEF territory. In the shadow of sterling's devaluation, Wilson feared the economic implications of a strike: if it upset overseas speculators, confidence in the currency might collapse. ${ }^{57}$ Taking this into account, Gunter's television broadcast explaining the context of the dispute was remarkably sympathetic to ASLEF's plight. He described the union as representing the 'aristocrats of railwaymen' and noted officials' 'understandable pride'. Gunter then gave a sensitive outline of the unions' position, even though he concluded that any action would be unjustified..$^{58}$

This is not to say Wilson was unaware of the political advantages of defeating a union, given the right circumstances. As the Prime Minister's Private Secretary stated in 1965, he 'would be glad to find a case of a strike of unskilled men for which there was no legitimate grounds and in which a direct attack on the public was involved' so he might send in the troops. Wilson initially thought a dispute concerning milk delivery at United Dairies in London was such an occasion, but he was persuaded that, before soldiers could commandeer the milk floats, a state of emergency would have to be called. As a result he lost enthusiasm for the scheme. ${ }^{59}$

Leftist critics thought Wilson's conduct during the prolonged 1966 seamen's strike vindicated their suspicion that the government would support employers against workers whatever the legitimacy of the latter's case. ${ }^{60}$ In fact, from the outset Wilson put numerous compromise formulae to the National Union of Seamen (NUS) to avoid a strike he knew would have a severe economic impact. ${ }^{61}$ In particular, he proposed establishing an inquiry to consider reforming the draconian legislation that governed seafarers' conditions. The Prime Minister was, however, unwilling to allow the NUS to gain what it wanted, in effect a pay rise of 20 per cent, as that would have blasted a hole in his attempt to keep 
wage costs down. Nor was Wilson alone in becoming frustrated with the union's rejection of attempts to find common ground: so irritated did the TUC become, it withdrew support for the NUS. ${ }^{62}$ Thus, when the Prime Minister asserted that the dispute was due to the influence of a 'tightly knit group of politically motivated men', he did so with what he imagined was just cause. ${ }^{63}$ Not all of Wilson's colleagues were convinced, and looked on his claims as evidence of Prime Ministerial paranoia: Peter Shore even thought his boss had gone 'completely bonkers' ${ }^{64}$

Whatever the merits of Wilson's case, Communist influence was a deus ex machina that appeared to explain why the strike continued for so long. The Prime Minister believed the intervention of CP members was the only plausible explanation why an 'otherwise sturdy union', composed of 'realistic and reasonable men', allowed the strike to drag on. That some of the union's executive were, as he put it, 'very close' to Communists was undoubtedly true and it was known that these figures exerted a disproportionate, if legitimate, influence within the union's upper echelons. Such was their sway that they discouraged moderate but feeble executive members from openly calling for a return to work. Indeed, Wilson's rhetoric was partly aimed at shaming into action those he thought lacked backbone. ${ }^{65}$

For the most part, the Prime Minister - and even the security services - saw Communist influence as an irritant but not the basic cause of most disputes. ${ }^{66}$ Ministers were much more concerned with their lack of a proper administrative device to prevent disputes reaching the point at which production would be disrupted. As Lord Brown, an industrialist Wilson made a junior minister at the Board of Trade, suggested, much of the hostility marking employer-employee relations was due to 'sheer confusion'. ${ }^{67}$ That so many strikes in key industries were 'unofficial', that is, called without formal union sanction, added weight to the view that if only agreements were adhered to, and appropriate conciliation machinery were put in place, harmony could be maintained. To that end, ministers promoted a variety of joint management-union remedies, most especially in the strike-prone motor industry. They also supported giving union leaderships more power. In 1965 Gunter proposed that the motor unions should revoke the membership of workers who took unofficial action. In return, he wanted employers to require all employees to join a union. If this arrangement would increase union influence at the workplace, it also meant dissidents would be barred from working in the industry. ${ }^{68}$ Unfortunately for Gunter, union leaders such as Hugh Scanlon of the Amalgamated Engineering Union (AEU) and Jack Jones of the Transport and General Workers' Union (TGWU) were inclined to reflect the demands of workers ministers viewed as trouble-makers. ${ }^{69}$ 


\section{Defending the unions?}

The Wilson governments are generally assumed to have antagonised Labour activists, largely because of the extent to which their policies were thought to harm the unions. After 1966 the leadership certainly suffered numerous reverses at conference over policies delegates felt hurt workers' interests. It is, however, impossible to be sure how far these conference decisions represented the views of union leaders, who were able to cast their block votes, rather than those of constituency delegates, although one authoritative assessment suggests most of the latter supported ministers' attempts to control wages. ${ }^{70}$

It would be wrong, therefore, to imagine that all activists thought their first duty was to defend the unions: given that only one-quarter of manual workers routinely sympathised with strikers during an industrial dispute, this should not be surprising. ${ }^{71}$ One member of Clapham's women's section asked, as early as 1957, 'if workers were pulling their weight' in the economy and suggested, on the basis that 'in order to take out we must also put in', the answer was in the negative. ${ }^{72}$ A leading Labour woman went even further in 1966, declaring that 'in return for a fair wage all workers must work to their utmost so their products could be sold'. Indeed, anyone 'who did not do that, or incited or joined in unofficial action did disservice to the Government and the Nation, and in wartime would have been referred to as Quislings'. ${ }^{73}$ Possibly with such comments in mind, one delegate to the 1963 national conference of Labour women stated that too many in the party were 'only too willing to condemn the trade unions and the industrial action they took' ${ }^{74}$

The left nonetheless believed that Labour should follow policies favourable to the unions, if only because they formed 'an enormous, and largely untapped potential of active support'. ${ }^{75}$ While Tribune MPs feared Wilson was alienating union leaders, that at least had the welcome consequence of encouraging unions to make common cause with the left. ${ }^{76}$ Michael Foot believed the shift leftwards of numerous union bureaucracies was 'one of the most significant events in modern British politics', because it meant the final transformation of Labour into a party fully committed to socialism was at hand. ${ }^{77}$ While the left therefore increasingly identified with the unions, Castle went a little far when noting Tribune's 'constant propaganda to the effect that every wage claim is sacrosanct and every industrial dispute noble'. ${ }^{78}$ If those on the left did not endorse every unofficial strike, they usually suggested such disputes arose from 'fundamental inequalities' and would stop only when the economy was transformed through more public ownership. ${ }^{79}$

Support for union demands was, however, less certain at the party's grass roots, and was contested even in CLPs that generally endorsed the Tribunite perspective, such as Chigwell and Ongar. ${ }^{80}$ There, in 1966, 
the executive committee (EC) placed before its general management committee (GMC) a motion endorsing the government's incomes policy, only to see it rejected by delegates, who condemned it as 'detrimental to the achievements of a Socialist Society'. Later in the year, the GMC was faced with two resolutions, one of which regretted the NUS strike while the other supported it: the former was defeated and the latter supported by the same six-to-four margin. Similarly, a later motion critical of an unofficial strike on the London docks took a Gunter-like line by calling on the TGWU to withdraw membership from participants; this also was lost. The balance of opinion, however, shifted in the wake of Castle's attempt to regulate industrial relations and to reduce unofficial strikes through her proposals set out in In Place of Strife. The GMC sent for the consideration of the 1969 conference a resolution expressing distress that some were:

completely deserting adherence to the cause of Socialism. This is most marked in the vocal sections misnamed 'the militants' who have succeeded in persuading the trade unionists in special key industries that they have no concern with the rest of the movement. They can, by a process of blackmail, obtain their demands even though, under Capitalism, these tend to be at the expense of the rest of the workers.

In other left-inclined local parties, support for the unions was conspicuous by its absence. In 1968 the Warwick and Leamington Spa GMC mandated its conference delegate: to protest against the imposition of prescription charges; to call for the North Atlantic Treaty Organisation to be disbanded; to dissociate the party from US policy in Vietnam; but to support the government's incomes policy. ${ }^{81} \mathrm{~A}$ similar contrast in attitudes was evident in Edinburgh South, whose GMC sided with the left over Vietnam, Rhodesia and South Africa but which refused to criticise the government's wages policy. ${ }^{82}$

\section{Industrial democracy}

'Industrial democracy' was described in 1967 as 'one of those splendid catch-phrases with which the Labour Movement is so richly endowed ... a safe subject to wax platitudinous about' ${ }^{83}$ If a harsh assessment, it was true that, although it was discussed with increasing fervour during the 1960s, industrial democracy remained a topic in need of clarification. Most Labour members supposed that increasing employees' involvement in management would help to improve industrial relations, but they remained at odds over the form such involvement should take, 
and even disputed its ultimate purpose. Precision was not helped by it being seen as but one aspect of the wider demand for individuals to 'participate' directly in decision-making, something discussed in Chapter 8 .

While some enthusiasts believed in the existence of a 'huge powderkeg' of interest in industrial democracy, others conceded that most workers were unaware of its importance and would need to be 'stimulated' to demand it. ${ }^{84}$ Survey evidence confirmed that workers were, at best, lukewarm. Fairly typical was a 1970 Ministry of Transport investigation into the attitudes of British Rail employees. This concluded that a majority were vaguely interested in contributing to decision-making but only if it was limited to being consulted by management rather than assuming responsibility themselves. Most were also concerned only with issues of immediate relevance to their own work. ${ }^{85}$ This reluctance to challenge managerial prerogatives confirmed Goldthorpe and Lockwood's suggestion that most workers adhered to an instrumental attitude to work. ${ }^{86}$ Given that they saw their job as an unpleasant means to an end, it was understandable why few employees wanted to spend time thinking about it any more than they had to. Most employers also angrily opposed any proposals that threatened their freedom to manage: John Davies, Director General of the Confederation of British Industry (CBI), considered that while managers 'should be susceptible to a great deal of advice and help ... that is as far as it should go' ${ }^{87}$ Leading civil servants in the Ministry of Labour were also sceptical and, only months before Wilson took office, had decided that most employees were incapable of assuming the necessary interest in their workplace to make it practical. $^{88}$

Increasing workers' influence had been the ambition of Labour members earlier in the century: co-operators, syndicalists and guild socialists aimed to give employees varying levels of managerial authority. Most unions, however, refused to countenance such schemes, and considered it best to pursue their interests unhindered. Therefore when Labour extended the public sector after 1945, the unions sought only participation in joint consultative committees, while a few retired general secretaries sat on nationalised boards, usually for industries of which they had no experience. ${ }^{89}$ Writing in 1949, the MP Eirene White expressed the general view when she asserted that these boards ran the nationalised sector on behalf of the whole community. Workers should not have representatives on these bodies, as that would compromise their ability to act for the nation, by tilting them too much in the direction of the employees' interest. It would also inhibit efficiency: managers still required the ability to take decisions workers might oppose. In any case, the fact of nationalisation, White believed, had eliminated a major disincentive to co-operation and so greater productivity: for miners and 
the like now laboured on behalf of the people rather than for the profit of a few capitalists. ${ }^{90}$

Despite such hopes, as the Attlee government drew to a close, the nationalised sector did not produce a marked increase in output: Mikardo, for one, believed this was partly because, consultation notwithstanding, publicly owned industries were still run in the traditional manner. Others held that the consultation machinery was adequate but believed neither managers nor unions took it seriously, because they remained obsessed with the notion of conflict. ${ }^{91}$ As the MP Austen Albu stated at this time, '[t]he creation of a feeling of common purpose in the activities of industry remains ... one of the outstanding unattained objectives of socialist industrial policy'. ${ }^{92}$

\section{An important issue?}

During Labour's years of opposition, how the party might promote this 'common purpose' did not exactly dominate members' horizons. Most remained preoccupied with maintaining full employment, improving incomes and debating how far the public sector should be extended. Yet, as Towards Equality put it, while full employment improved the 'traditional manager-worker relationship', an extension of industrial democracy was still required if it was to transform into a 'genuine partnership'. ${ }^{93}$

The failure of the Labour left to take up this issue was surprising given their critique of consultation. Left-wingers like Judith Hart, when seeking adoption as a parliamentary candidate, certainly felt it advantageous to refer to the need to give workers 'greater satisfaction and a greater sense of participation'. ${ }^{94}$ Indeed, Aneurin Bevan's In Place of Fear (1952) stressed how important it was that state employees experienced a more co-operative relationship, for, he argued, 'the individual citizen will still feel that society is on top of him until he is enfranchised in the workshop as well as at the ballot box'. ${ }^{95}$ As others argued later in the decade, industrial democracy was a matter of political rights. ${ }^{96}$ Yet, despite such fervour, thinking on the subject rarely became specific: to many, simply expressing their aspiration that workers should achieve a managerial role appeared sufficient. ${ }^{97}$

In contrast, two of the party's leading revisionists, Crosland and Douglas Jay, advanced clear proposals, although, like White, both questioned the wisdom of giving workers a direct say in management. ${ }^{98}$ As had White, both men believed there would always be two sides to industry, with management taking the decisions while the unions assumed the mantle of permanent opposition. Given the nature of the workplace it was, they asserted, unrealistic to impose notions of democracy applicable 
outside the factory gate. In any case, Crosland argued, workers did not need special measures to give them influence. Full employment, rising real wages, social security and 'a general change in the social climate' had eroded many managerial prerogatives. He nonetheless hoped cooperation would flourish outside the collective bargaining process; in particular, he suggested that workers should be given more opportunities to influence how their own tasks were allocated. Moreover, Crosland feared that incorporating the unions too closely within management would allow more disruptive - inevitably Communist - elements to usurp their role as the workers' representatives. Jay's outlook was similar and he opposed putting union officials on company boards, fearing officials would either suffer a conflict of loyalty or confuse the board's managerial function. However, he supported the election of employee representatives who were neither workers nor union officials. In this Jay echoed Albu's belief that worker representatives could 'ensure sanction for executive authority' and encourage employees to 'feel a direct ... responsibility for those who represent them in the making of management decisions'. ${ }^{99}$

During the first half of the 1960s some unions became more attracted to industrial democracy: it appears that affluence gave them the confidence to claim more than just higher wages. ${ }^{100}$ Evidence submitted by the TUC to the Donovan Commission on Trade Unions and Employers' Associations in 1965 revealed their tentative interest. This was, however, an uneven conversion, with Jack Jones of the TGWU and Hugh Scanlon of the AEU taking the lead. Both supported the Institute for Workers' Control, established in 1964 by the Nottingham Labour activist Ken Coates, whose conferences attracted upwards of 500 people, although many attendees had sympathies well to Labour's left. Jones was the single most influential voice on this matter. ${ }^{101} \mathrm{He}$ emphasised how participation could not only make 'life worth living' on the factory floor but also help overcome unnecessary 'misunderstanding, resistance, low morale and suspicion'. Ultimately, Jones aimed to foster a series of 'self-governing communities', within which workers exerted full control. If apparently idealistic, Jones was hard-headed enough to reject any form of industrial democracy conducted directly by individual workers because that threatened the privileged position unions occupied within the workforce.

Not all unions were convinced: the leadership of the Electrical Trades Union remained firm adherents of the view that unions should concentrate on improving wages and conditions and leave management to managers. ${ }^{102}$ In fact, it is possible that some union leaders who ostensibly supported industrial democracy saw it as no more than a means of increasing their ability to secure a more traditional objective: higher wages. ${ }^{103}$ 


\section{Jack Jones' influence}

Arguments about the merits of industrial democracy came to a head with the Wilson government's Iron and Steel Bill. This outlined Labour's plan to renationalise the steel industry but failed to make recommendations for involving workers in management, beyond consultation. Delegates at the 1965 Labour Party annual conference made their feelings clear and in response the NEC established a working party on industrial democracy. ${ }^{104}$ This led to a report debated at the 1967 conference, which formed the basis for an NEC statement endorsed by conference the following year: many of its recommendations found their way into Castle's Industrial Relations Bill of 1969.

Before the debate on steel, the NEC had commissioned an investigation chaired by Mikardo into the port transport industry, which the government was committed to taking into public hands. ${ }^{105}$ The object of Mikardo's Study Group, which counted Jones as a member, was to recommend what form state ownership should assume. As both men were well known critics of consultation, it came as no surprise when they proposed measures it was claimed would result in 'the injection of a new, radical element of industrial democracy'. The report argued that, for historical reasons, the dock unions - prominent among which was the TGWU - had unrivalled experience exercising joint authority with management and it proposed this should be extended to maintain harmony in a conflict-prone industry. In particular, the report recommended that a Group Operating Committee, to which managers would be responsible, should run each dock. This was described as a 'breakthrough' because sitting on the Committee would be representatives elected by the workforce, who would enjoy an unprecedented influence over discipline, safety, training, welfare and - most radically - wages.

While the Mikardo report justified its proposals in relation to the unique character of the ports, Jones, for one, believed they should be applied to other industries and was given the chance to influence that outcome when he was appointed chair of an NEC working party on industrial democracy. ${ }^{106}$ The outward aim of this body was to make work a more satisfying experience, in the expectation that this would improve industrial relations. This would, of course, benefit everybody, including what was said to be an increasing number of employers interested in giving employees more responsibility. If treating workers as equals rather than subordinates gave them unprecedented autonomy, it would also help managers to exploit their 'untapped talent'. ${ }^{107}$ In particular, the creation of mutual trust would help industry adapt to the consequences of technological change, something that otherwise might generate an insecure and strike-prone workforce. Thus, one of the purposes of reform was to reveal the compelling common interest that united both sides of 
industry, by creating individuals 'with a widening range of social understanding, and a responsible and democratic approach to individual and group problems'.

Most members of Jones' working party believed there was no limit to how much managerial responsibility workers might exert. So far as the Labour leadership was concerned there were some. Responding on behalf of the NEC to the 1965 steel debate, White reaffirmed her view that 'the tradition on which our trade union movement had grown up, does not lend itself to workers' control'. ${ }^{108}$ Reflecting his union's position before Scanlon's election as President, the AEU official Bill Simpson also feared too much democracy might imperil efficiency, whereas the former should always be subordinated to this 'paramount factor'. ${ }^{109}$ Similarly, the MP Eric Moonman believed the rights claimed by workers and managers were mutually exclusive and argued '[m]anagement must manage', albeit supported by committees promoting greater worker involvement. ${ }^{110}$

While one of its authors described the 1967 report as revolutionary, its proposals were nonetheless justified in terms designed to appeal to the gradualist strain in Labour thinking. ${ }^{111}$ Hence, it recommended industrial democracy be extended 'not by evolving new and complex (and perhaps alien) structures, but by gradually increasing involvement in a development of existing machinery ... it would encourage a movement towards participation in democratic procedures; a natural evolution rather than an attempt to conjure democracy out of the air'. In concrete terms, this meant industrial democracy would proceed through 'accredited representative[s] of working people': the unions. ${ }^{112}$ So far as Jones was concerned it meant stronger unions, and implied: giving them the right to be recognised by any employer; granting them access to confidential company information; increasing compensation to workers faced with redundancy; and providing better training for their representatives. Rather than needing separate consultative committees, industrial democracy would be expressed through the same channel that dealt with wages. As Simpson noted, this meant consultation would be linked to that basic union concern, so co-operation over a whole range of matters could be made dependent on financial reward. ${ }^{113}$ While no specific form of industrial democracy was prescribed although Mikardo's scheme was cited as worthy of emulation - indicative examples significantly included giving unions responsibility for distributing overtime and deciding on promotions.

Delegates reaching the rostrum during debates on industrial democracy held at the 1967 and 1968 conferences wanted full workers' control of management and saw Jones' labours as an initial step towards that end. ${ }^{114}$ They were mostly sceptical about co-operation and partnership with management, and criticised measures that did not lead to greater 
union authority at the workplace. Jones appeared to sympathise with them, calling in 1968 for union representatives to 'invade the powers of the bureaucrats in industry' and limit the 'dictatorial and unilateral authority of management'. ${ }^{115}$ How far conference reflected the views of the rest of the party is hard to say, as few CLPs debated the matter. While the 1967 NEC report was supposed to be the basis for party-wide consultations, Transport House received few comments. ${ }^{116}$ If measured in column inches, Tribune's interest was also limited. In addition, the 1968 debate was conducted over the incessant chatter of delegates, presumably talking about other matters, and the chair was forced to remind them of the subject's importance. ${ }^{117}$

\section{The impact of Barbara Castle}

Jones believed the government should implement the 1968 NEC statement without delay, in the first instance within the public sector. ${ }^{118}$ Few advocates of workers' control were optimistic, for while Ken Coates welcomed the Jones report as a step in the right direction, he considered ministers were 'driving full speed in the opposite direction'. ${ }^{119}$ This was not entirely accurate. Taking their lead from Crosland and Jay, most ministers opposed radical reform but were nonetheless willing to consider variations of, if not alternatives to, consultation. Moreover, as the Cabinet's greatest enthusiast for innovation, Barbara Castle, first as Minister of Transport and then First Minister of State at the DEP, pushed colleagues towards a serious consideration of industrial democracy.

Like Mikardo, Castle supported Bevan during the 1950s and wanted to 'forge ahead' with worker participation, to which end she regularly consulted Jones, although he thought she found his ideas too anarchistic. ${ }^{120}$ As Minister of Transport, Castle nonetheless wanted to apply Mikardo's recommendations. She made it clear that her 'overriding consideration' was to 'give the individual dock worker ... the feeling that his interests are being directly safeguarded by the presence of his representatives $\ldots$ at the meetings ... where matters affecting his livelihood are being discussed'. Yet while she wanted to 'associate workers with management without handicapping management', employers' representatives opposed making managers answerable to bodies on which sat union officials. ${ }^{121}$ Castle's Cabinet colleagues were also uncertain. Presumably because he did not want to antagonise the unions, Gunter agreed that worker participation should be a 'central feature' of the nationalised docks. However, he felt that it would be unwise to give employee representatives an influence over wage negotiations and proposed that each dock should merely have a consultative committee, albeit one with direct access to management. Michael Stewart at the 
Department of Economic Affairs echoed Gunter's concern that union officials sitting on Group Operating Committees would be unable to assume a 'detached and dispassionate interest' over wages. Moreover, if they did acquire that outlook, the unions might then alienate their members, leaving the door open to unofficial strikes and far-left influence. ${ }^{122}$

In light of these comments, Castle decided against making any specific proposals for industrial democracy. Instead, she drafted some general principles favourable to increasing participation, in the hope they would be anodyne enough to pass Cabinet scrutiny but still allow the unions to use them to justify Mikardo-like experiments once the ports were nationalised. Yet, when the Ports Bill was finally published in November 1969, the wording was too vague for the unions. Their demand for an unequivocal promise that workers would play a managerial role was not unrelated to their belief that this would help them prevent the introduction of new labour-saving technologies. It was because he feared the unions would exploit any managerial function to prevent such innovation that the then Minister of Transport, Fred Mulley, refused to make legislation less obscure. ${ }^{123}$ In the end, the Bill fell due to Labour's loss of power.

Although she was forced to make a tactical retreat on the docks, Castle tried to create a statutory framework for worker representation on the boards of state-owned industries under Ministry of Transport control, and was adamant that active union officials should be allowed to sit on these bodies. ${ }^{124}$ She believed the established practice of appointing retired trade unionists with no experience of the industry on whose board they sat had done nothing to ensure workers were 'more closely identified with the policies adopted for the industry' and so might 'assume management habits of thought'. If the initial draft of Castle's proposals was anything to go by, her civil servants nonetheless feared the presence of union representatives would create conflicts of interest: in particular, it might allow them to influence wage negotiations from both sides of the table. ${ }^{125}$ This echoed the view of leading board members and even that of some unionists, for the TUC's Nationalised Industries Committee received her proposals with some caution. Once again forced to rethink, Castle conceded that union representatives should not be involved in all board activity. When this did not go far enough for her detractors, rather than make immediate legislative proposals, Castle agreed to sponsor experimental schemes, in the hope that these would eventually generate support for her objective. ${ }^{126}$

In April 1968 Castle was moved from the Ministry of Transport. Her replacement, Richard Marsh, was hostile to any form of worker participation; indeed, Castle believed he had no 'feel for Socialist ideas at all'. ${ }^{127}$ Marsh was certainly unwilling to allow union officials to sit on nationalised boards, as he was convinced they would inevitably adhere 
to union policy and so undermine managerial decision-making. This remained his view even after union officials conceded that full-time board members might relinquish their union posts while part-timers could stand aloof when wages were discussed. Even so, while Marsh thought consultative councils were the best means of promoting participation, he promised to do what Castle would have done, that is, draft the forthcoming Transport Bill in such a way as not to preclude experimentation. ${ }^{128}$ He also commissioned a survey of British Rail employees' attitudes to industrial democracy, which, after numerous delays, began in March 1970 and so was concluded only after Labour had lost power. It is doubtful this would have led to radical action even had Wilson won re-election, for its conclusions, referred to above, were not encouraging. ${ }^{129}$

\section{In place of shareholders?}

Once installed at the DEP, Castle formulated a White Paper devoted to improving industrial relations, which she entitled In Place of Strife. Most union leaders and all the Labour left believed this represented Castle's desire to undermine workers' ability to hold strikes. ${ }^{130}$ Wilson and his closest advisers were certainly concerned that, as his economic guru Thomas Balogh put it, the unions had become 'an irresponsible group who had to be dealt with'. ${ }^{131}$ The Prime Minister consequently looked on Castle's proposals for compulsory strike ballots and the imposition of 'cooling off' periods before strikes could be held as ingenious devices to prevent unofficial disputes.

Yet, whatever might have been thought, Castle wanted to strengthen the unions rather than weaken them, and much of In Place of Strife was preoccupied with that aim. ${ }^{132}$ In fact, one of her 'principal objectives' was to promote industrial democracy. Paragraph 49 was strongly influenced by the NEC's 1968 statement and endorsed the view that the best way to develop participation 'must be through a reform, extension and strengthening of collective bargaining' and the creation of a strong union movement. Castle saw this as fully endorsing the "philosophic rightness' of allowing employees to influence decision-making. ${ }^{133}$ The subsequent Bill consequently was to make it illegal for workers to be denied union membership or to be subject to discrimination once members; it also introduced the notion of 'unfair dismissal'. Employers were to be obliged to make available information considered relevant to wage bargaining. In addition, the Bill proposed regulating the position of shop stewards, by providing training and facilities to help them better perform their tasks; it also outlined plans to subsidise the training of both union officials and members, to enable them to participate more effectively. Most relevantly, Castle committed the government to undertake 
experiments involving placing worker representatives on the boards of nationalised industries. ${ }^{134}$ Castle had only started consulting on what form these trials might take when Wilson announced the election date. ${ }^{135}$

One reason why experimentation was to take place initially in the public sector was that company law effectively prevented workers acquiring a managerial role outside it. Castle called for the law to be reformed. This the CBI inevitably opposed, as the existing statutes meant directors could be appointed only by shareholders rather than elected by workers, while all board members were obliged to accept collective responsibility and maintain the shareholders' interest. The Board of Trade, busy with other matters, echoed that view. ${ }^{136}$ Yet there was some prospect of change, for, in 1967, when in charge of the Board, Jay had outlined his intention to introduce a systematic review of company law. In particular, he wanted to oversee the 'comparative rights and obligations of shareholders, directors, creditors, employees and the community as a whole'. ${ }^{137}$ The Board in fact aimed to introduce legislation some time after the election; its proposals regarding company philosophy were informed by the findings of an NEC study group. ${ }^{138}$ Quite how radical these would have been is uncertain. Lord Brown, Minister of State at the Board, marked out its possible limits by adamantly opposing the creation of elected worker directors, arguing on the familiar grounds that this would mean board business being dominated by surrogate wage negotiations. ${ }^{139}$ Despite that, Labour's 1970 manifesto promised to reform company law and extend experiments in industrial democracy to the private sector.

\section{Conclusion}

As with those that follow, the main purpose of this chapter is to highlight the underlying reasons why the party embraced the policies it did, rather than to assess their impact. This was just as well, for at the time of leaving office Wilson's governments had made only a negligible impression on secondary education and industrial democracy.

The commitment to end segregated education was widely shared across the party, linking revisionist ministers to Tribune-reading activists; while the former advocated gradual progress and the latter urged immediate action, differences were limited to means, not ends. Thus, in explaining why only one-third of children were being taught in a comprehensive school by 1970, the Department of Education's limited powers should be taken into account. The failure to reform private education largely followed from the Cabinet's reluctance to confront the numerous practical and political problems raised by the issue at a time when Labour was already deeply unpopular. That the final official 
report into the issue was not produced until just before the 1970 general election was clearly a significant additional factor.

In contrast, no progress towards even the most modest forms of worker participation had been made as Labour ministers emptied their desks. There were, it is true, a dozen part-time 'worker directors' in the newly nationalised steel industry sitting on advisory regional boards. However, this initiative owed little to Labour ministers and was, in any case, widely criticised by advocates of industrial democracy as little more than glorified consultation. ${ }^{140}$ Labour's lack of action was largely due to the fact that it was such a contentious issue within the party. The left wanted workers to exert at least co-determination with management; some even called for full workers' control. If most ministers (and some union leaders) were willing to enhance the means by which employees were consulted, they feared efficiency would be compromised if workers played a direct managerial role. How far each side of this argument was truly committed to reconciling workers and managers so that each might work together to advance the common interest is moot. Even so, largely due to the efforts of Barbara Castle, before the 1970 campaign the government was committed to introducing a number of experimental schemes that would have tested the nature of party members' intentions.

\section{Notes}

The place of publication is London unless otherwise specified.

1 Labour Party, Towards Equality (1956), pp. 3-4.

2 C. A. R. Crosland, The Future of Socialism (1956), pp. 105, 112-14.

3 House of Lords Record Office, Reginald Sorenson papers, Hist. Coll. 102/ 230, A backbencher's pilgrimage, 1968, p. 67.

4 Labour Party Archive (LPA), Bagshot and Egham Clarion, January 1965.

5 Labour, Equality, p. 14.

6 H. Gaitskell, 'The economic aims of the Labour Party', Political Quarterly, 26 (1956); C. A. R. Crosland, The Conservative Enemy (1962), pp. 173-4.

7 H. Gaitskell, 'Public ownership and equality', Socialist Commentary, June 1955, and 'Socialism and nationalisation', Fabian Tract, 300 (1956), p. 3.

8 See, in particular, L. Panitch, Social Democracy and Industrial Militancy (Cambridge, 1976).

9 Report of the Sixty-Eighth Annual Conference of the Labour Party (1969), p. 341.

10 Labour Party, Let's Go with Labour for the New Britain (1964), pp. 13-14; and Labour Party, Time for Decision (1966), pp. 15-16.

11 This account is based on M. Francis, Ideas and Policies Under Labour 19451951 (Manchester, 1997), pp. 141-68.

12 D. Rubinstein and B. Simon, The Evolution of the Comprehensive School (1973), pp. 52-68.

13 M. Parkinson, 'The Labour Party and the organisation of secondary education', MA thesis, University of Manchester, 1968, pp. 183-95.

14 Report of the Fifty-Seventh Annual Conference of the Labour Party (1958), pp. 87-8. 
15 LPA, Study Group on Education (SGE) papers, M. Stewart and M. Cole, Memorandum on Labour Party policy for education, Re. 161/May 1957.

16 Crosland, Future, p. 258; Labour, Equality, pp. 5-6.

17 Report of the Sixty-Ninth Annual Conference of the Labour Party (1970), pp. 91, 94.

18 London Metropolitan Archive (LMA), London News, April 1953.

19 LPA, Abingdon Labour Party Constituency Digest, August 1963.

20 British Library of Political and Economic Science (BLPES), North Kensington CLP papers, North Kensington Labour Questionmaster, June 1952 and September 1955.

21 SGE papers, minutes, 16 July 1957.

22 SGE papers, minutes, 19 December 1957, and Brief summary of the findings of the survey on educational attitudes, Re. 314/February 1958.

23 Bristol Record Office (BRO), Labour Party South West Region papers, 38423/43, News-Sheet, July 1964.

24 Report of the Sixty-Sixth Annual Conference of the Labour Party (1967), p. 124.

25 Sixty-Seventh Annual Conference of Labour, p. 231.

26 Modern Records Centre (MRC), Warwick and Leamington Spa CLP papers, MSS 133, Box 10, Contact, July/August and September/October 1966.

27 See, for example, D. Marsden, 'Politicians, equality and comprehensives', in P. Townsend and N. Bosanquet (eds), Labour and Inequality (1972).

28 S. Crosland, Tony Crosland (1982), p. 148.

29 SGE papers, minutes, 16 July 1957 and 29 January 1958.

30 Public Record Office (PRO), ED 207/22, A. Crosland, Draft note for the Prime Minister, October 1967.

31 Sunday Telegraph, 19 October 1969.

32 Crosland, Conservative, p. 174.

33 K. O. Morgan, Labour in Power, 1945-1951 (Oxford, 1985), pp. 177-9; Francis, Ideas, pp. 159-63.

34 Report of the Fifty-Second Annual Conference of the Labour Party (1953), pp. 172-3.

35 Crosland, Conservative, pp. 180-1.

36 SGE papers, minutes, 11 December 1957.

37 SGE papers, Report of weekend conference on education, 7/9 February 1958, Re. 323/February 1958; Crosland, Conservative, p. 180.

38 SGE papers, Brief summary of the findings of the survey on educational attitudes, Re. 314/February 1958.

39 SGE papers, minutes, 19 February 1958.

40 Stewart and Cole, Memorandum.

41 Labour Party, Signposts for the Sixties (1961), pp. 31-2.

42 Report of the Sixtieth Annual Conference of the Labour Party (1961), p. 136.

43 PRO, PREM 13/2069, Mitchell to Cockerill, 17 May 1965, and Mitchell to Litton, 18 May 1965.

44 PRO, CAB 129/123, Public schools, Memorandum by the Secretary of State for Education and Science, C(65)155; Editorial, 'The politics of education', Socialist Commentary, February 1966; Crosland, Crosland, p. 149.

45 Sixty-Sixth Annual Conference of Labour, pp. 133-4.

46 J. Rae, The Public School Revolution (1981), pp. 38-46.

47 PREM 13/2069, Trend to Wilson, 17 July 1968; CAB 129/138, Public Schools Commission: First Report, C(68)86; CAB 128/43, 18 July 1968; T. Benn, Office Without Power. Diaries 1968-72 (1988), p. 91.

48 Sixty-Seventh Annual Conference of Labour, pp. 235-6, 240. 
49 A. Goodwin, 'Education without privilege', Socialist Commentary, May 1970.

50 Sixty-Ninth Annual Conference of Labour, p. 99.

51 B. Castle, The Castle Diaries, 1964-1976 (1990), p. 34.

52 I. Mikardo, 'Trade unions in a full employment economy', in R. H. S. Crossman (ed.), New Fabian Essays (1952), pp. 143-4, 147-8; Crosland, Conservative, p. 219.

53 Edinburgh Evening News, 29 November 1962.

54 PREM 13/403, Note of a meeting held at Downing Street, 26 October 1964; PREM 13/978, Notes of the proceedings of the National Conference on Productivity, 27 September 1966. For more on the importance of productivity, see J. Tomlinson, The Labour Governments 1964-70. Vol. 3: Economic Policy (Manchester, 2004), chapter 8.

55 D. E. Butler and A. King, The British General Election of 1964 (1965), pp. 115-16; PREM 13/606.

56 PREM 13/786, The Communist party and the threatened railway strike, 22 February 1966.

57 PREM 13/1847, Record of a meeting between H. Wilson and R. Gunter, 29 November 1967.

58 PREM 13/1847, Text of ministerial broadcast by R. Gunter, 3 December 1967.

59 PREM 13/607, Mitchell to McIndoe, 10 June 1965.

60 P. Foot, 'The seamen's struggle', in R. Blackburn and A. Cockburn (eds), The Incompatibles: Trade Union Militancy and the Consensus (Harmondsworth, 1967); and K. Coates, The Crisis of British Socialism (Nottingham, 1971), pp. 133-42. For a more measured view, see K. Thorpe, 'The "juggernaught method": the 1966 state of emergency and the Wilson government's response to the seamen's strike', Twentieth Century British History, 12:4 (2001).

$61 \mathrm{CAB} 130 / 465$, Minute of meeting with the Executive Committee of the National Union of Seamen, 13 May 1966.

62 CAB 130/465, Minute of meeting with the Finance and General Purposes Committee of the TUC, 14 June 1966; PREM 13/1228, Note of a meeting held at 10 Downing Street, 9 June 1966.

$63 \mathrm{~J}$. McIlroy, 'Note on the Communist Party and industrial politics', in J. McIlroy, N. Fishman and A. Campbell (eds), British Trade Unions and Industrial Politics. Volume II (Aldershot, 1999), p. 241.

64 T. Benn, Out of the Wilderness. Diaries, 1963-67 (1987), p. 436.

65 PREM 13/1228, Note of a meeting between H. Wilson and D. Rusk, 10 June 1966, and Note of a meeting between H. Wilson and E. Heath, 21 June 1966; H. Wilson, The Labour Government, 1964-70 (Harmondsworth, 1971), p. 308.

66 PRO, LAB 43/535, The industrial situation, 30 April 1969.

67 PRO, BT 298/263, Lord Brown, Points to be considered for the Second and Third Companies Acts, 29 July 1967.

68 PREM 13/402, Note of meeting between the Prime Minister and representatives of the motor industry, 3 September 1965.

69 H. Scanlon, 'The role of militancy', New Left Review, 46 (1967), pp. 5, 15.

70 L. Minkin, The Labour Party Conference (1978), pp. 88-90.

71 D. Weakliem, 'Class consciousness and political change: voting and political attitudes in the British working class, 1964-1970', American Sociological Review, 58:3 (1993), pp. 385-90.

72 Lambeth Archives, Clapham CLP papers, IV/156/2/5, Clapham Central women's section minutes, 2 October 1957. 
73 Report of the Forty-Third National Conference of Labour Women (1966), p. 18.

74 Report of the Fortieth National Conference of Labour Women (1963), p. 37.

75 Tribune, 11 March and 27 June 1966.

76 LPA, Ian Mikardo/Jo Richardson papers, Box 5, Tribune Group minutes, 8 November 1968, E. Heffer, Role of the group and its future work.

77 Tribune, 14 February 1969.

78 Castle, Diaries, p. 231.

79 Mikardo/Richardson papers, Box 5, Tribune Group minutes, 21 April 1969.

80 This account is based on Essex County Record Office, Chigwell and Ongar CLP papers, D/Z 84/3, 8023 GMC minutes, 23 March and 27 June 1966, 26 July and 27 November 1967, 23 June 1969.

81 Warwick and Leamington Spa CLP papers, MSS 133, Box 1, GMC minutes, 19 September 1968.

82 National Library of Scotland, Edinburgh South CLP papers, Dep. 203/4, GMC minutes, 28 July and 27 October 1966.

83 J. Torode, 'What is industrial democracy?', Socialist Commentary (July 1967), p. 30.

84 K. Coates, 'Democracy and workers' control', in P. Anderson (ed.), Towards Socialism (1965), pp. 294-5; Scanlon, 'Militancy', pp. 9-10; K. Coates and T. Topham, 'The Labour Party's plans for industrial democracy', Institute for Workers' Control Pamphlet No. 5 (Nottingham, 1968).

85 J. Edmonds, 'The worker', in B. Lapping and G. Radice (eds), More Power to the People (1968), pp. 39-40; PRO, MT 87/224, Tavistock Institute Inquiry into Worker Participation in Decision-Making in British Railways. Summary of findings and Worker Participation in British Railways Steering Group minutes, 9 August 1971.

$86 \mathrm{~J}$. H. Goldthorpe, D. Lockwood, F. Bechhofer and J. Platt, The Affluent Worker: Industrial Attitudes and Behaviour (Cambridge, 1968), pp. 108-9.

87 The Times, 29 July 1968.

88 LAB 10/2994, Minutes of Working Party on Workers' Attitudes and Industrial Efficiency, 26 June 1964; LAB 10/3061, Heron to Clucas and Marre, 17 April 1967.

89 R. Currie, Industrial Politics (Oxford, 1979), pp. 157-64.

90 E. White, 'Workers' control?', Fabian Society Challenge Series Pamphlet No. 4 (1949), p. 27.

91 J. Tomlinson, Democratic Socialism and Economic Policy (Cambridge, 1997), pp. 117-23; Francis, Ideas, pp. 78-83.

92 A. Albu, 'The organisation of industry', in Crossman, New Fabian, pp. 129-30.

93 Labour, Equality, pp. 9-10.

94 LPA, Judith Hart papers, Section 1, File 1 (ii), speech to selection meeting, Lanark, 1957.

95 A. Bevan, In Place of Fear (1952), pp. 102-3.

96 C. Jenkins, 'The retreat from industrial democracy', Focus, 5 (1956), p. 15.

97 H. Jenkins, R. Lewis, G. Southgate and W. Wolfgang, 'The red sixties', Victory for Socialism Pamphlet (1957), pp. 10-11.

98 Crosland, Conservative, pp. 217-27; D. Jay, Socialism in the New Society (1962), pp. 325-33.

99 Albu, 'Industry', pp. 136-7.

100 H. Scanlon, 'The way forward for workers' control', Institute for Workers' Control, Pamphlet No. 1 (Nottingham, 1968); Coates, 'Democracy', pp. 304-5.

$101 \mathrm{~J}$. Jones, 'The right to participate - key to industrial progress', TGWU Pamphlet (1970).

102 Torode, 'Industrial democracy', pp. 30-1. 
103 Edmonds, 'The worker', p. 38; Currie, Industrial, pp. 224-7.

104 Report of the Sixty-Fourth Annual Conference of the Labour Party (1965), pp. 252-6.

105 Labour Party, Report of the Port Transport Study Group (1966); J. Jones, Union Man (1986), p. 174.

106 Unless otherwise stated this section is based on Labour Party, Industrial Democracy (1967), and Sixty-Seventh Annual Conference of Labour, pp. 344-7.

107 LPA, Industrial Democracy Working Party (IDWP) papers, Proposed conference on industrial democracy, Res. 13/June 1966.

108 Sixty-Third Annual Conference of Labour, pp. 255-6.

109 IDWP papers, W. Simpson, Industrial democracy, Re. 28/July 1966.

110 Guardian, 22 July 1966.

111 Institute for Workers' Control, Report of the 5th National Conference on Workers' Control and Democracy (Nottingham, 1967), p. 27.

112 IDWP papers, J. Jones, Action points on industrial democracy, Re. 105/ March 1967.

113 Sixty-Seventh Annual Conference of Labour, pp. 160-1.

114 Ibid., pp. 156-7.

115 Ibid., p. 158.

116 IDWP papers, Industrial democracy. A draft action programme, Re. 49/ February 1968.

117 Sixty-Seventh Annual Conference of Labour, p. 157.

118 Ibid., pp. 158, 347; Labour, Industrial Democracy, p. 13.

119 Coates, Socialism, pp. 197-8.

120 Castle, Diaries, p. 206; Jones, Union, p. 193.

$121 \mathrm{LAB} 10 / 3061$, Minutes of meeting to discuss workers' participation in the nationalised ports, 30 January 1967; LAB 10/3061, Castle to Stewart, 8 March 1967.

122 LAB 10/3061, Gunter to Castle, 21 March 1967; Stewart to Castle, 31 March 1967; Castle to Stewart, 11 May 1967.

123 J. Horner, Studies in Industrial Democracy (1974), pp. 146-7, 153-4; MT 87/ 222, 'Ports Bill. Meeting with the TUC', 20 January 1970; Guardian, 17 March 1970.

124 MT 87/145, Workers' participation, 13 February 1968.

125 MT 87/145, Worker representation on the boards of nationalised transport industries, February 1968; Scott-Malden to Heaton, 16 February 1968.

126 MT 87/160, Note of minister's meeting, 5 March 1968; Note of B. Castle's meeting with Sir R. Wilson and H. C. Johnson, 15 March 1968; Note of minister's meeting with the Nationalised Industries Committee of the TUC, 25 March 1968.

127 Castle, Diaries, p. 248.

128 MT 87/200, Woodcock to Marsh, 8 April 1968; Note of R. Marsh meeting with the Nationalised Industries Committee of TUC, 10 May 1968; Note of R. Marsh meeting with A. Kitson, 16 May 1968.

129 MT 87/223; MT 87/224, Worker Participation in British Railways Steering Group minutes, 9 August 1971.

130 Jones, Union, p. 207; Tribune, 10 January 1969.

131 Benn, Office, pp. 122-3.

132 Castle, Diaries, p. 296.

133 LAB 43/558, Castle to Shore, 15 January 1970; LAB 10/3445, Castle to Burgh, 30 January 1969.

$134 \mathrm{LAB} 43 / 558$, The NEC statement on industrial democracy and the relevant provisions in the industrial relations legislation, January 1970. 
135 LAB 10/3445, Appointment of workers' representatives to the boards of public and private undertakings - discussion document, 5 March 1970.

136 LAB 10/3445, Bayliss to Mason, 1 April 1969, Brownsport to Simons, 14 May 1969.

137 LAB 28/396.

138 BT 298/263, Peck to Jardine et al., 18 October 1967.

139 Brown, Points to be considered.

140 T. K. Jones, 'Employee directors in the British Steel Corporation', in C. Balfour (ed.), Participation in Industry (1973). 